\title{
KOMUNIKASI POLITIK MEDIA SURAT KABAR DALAM STUDI PESAN REALITAS POLITIK PADA MEDIA CETAK RIAU POS DAN Tribun PEKANBARU
}

\author{
Hefri Yodiansyah \\ Sekolah Tinggi Ilmu Sosial dan Ilmu Politik Yayasan Pendidikan Persada Bunda Pekanbaru
}

\begin{abstract}
ABSTRAK
Pada era demokrasi, kebebasan informasi masih dalam tataran pemikiran, niat, kekuatan, dan pemodalan media massa. Politik berdampak terhadap tuntutan demokratisasi bernegara yang "good ideas" melalui pemilihan umum yang berkeadilan, dan kesadaran pemilih akan situasi dan kondisi masyarakatnya. Penelitian ini membahas tentang iklim komunikasi politik dan pemilihan umum kepala negara. Untuk menganalisis data, peneliti menggunakan perangkat analisis framing berdasarkan model Zhongdang Pan dan Gerald M. Kosciki yang pernah dikemukakan oleh Zhongdang Pan dan Gerald M. Kosciki yang terdiri dari 4 (empat) elemen makna dalam memaknai ideologi, yaitu struktur sintaksis, skrip, struktur tematik, dan retoris. Dengan analisis framing tidak hanya terbatas pada kerangka teori dalam mewacanakan bahasa politik dalam teks berita media massa. Akan tetapi, sekaligus dapat sebagai metode analisis untuk studi media massa (media studies). Temuan penelitian mencakup dinamika komunikasi politik, komunikator, pasangan kandidat, massa pendukung, media massa, dan partisipasi pemilih dalam menggunakan hak pilihnya, dan kualitas legitimasi politik menuju pemilihan umum berwibawa dan bermartabat. Ini merupakan faktor-faktor penting pendukung keberhasilan pelaksanaan pemilihan umum yang berkualitas.
\end{abstract}

Kata-kata kunci: Media massa, politik, framing, analisis kritis, komunikasi politik

\section{POLITICAL COMMUNICATION IN THE STUDY OF MEDIA NEWSPAPERS POLITICAL REALITY MESSAGES}

\section{ABSTRACT}

Freedom of information as an effort in the thoughts, intentions, strengths, and the capitalization of the media over democratic demands. Politic impacted to demands of democratization state that "good ideas" through fair elections and generate political candidates and voters who know the situation and condition of the society. This study of the climate of political communication and election head of state aims to provide a formulation of the topic of political discourse in order to contribute information needed in the general election. The findings of the study include the dynamics of political communication, communicators; a couple of candidates, supporters, the media, and voter participation in using their voting rights, and the quality of political legitimacy to the electoral authority and dignity. This is the important factors supporting the successful implementation of quality elections. This study uses a qualitative methodology that places the emphasis on tracking and triangulation of data sources related to the presidential and vice presidential elections.

Keywords: Mass media, politics, framing, criticalanalysis, political communication

Korespondensi: Hefri Yodiansyah, S.Sos, M.I.Kom. Yayasan Pendidikan Persada Bunda Sekolah Tinggi Ilmu Sosial dan Ilmu Politik, Program Studi Ilmu Komunikasi, Jln. Diponegoro No. 42, Riau, Pekanbaru 28116.Email: hefri.yordiansyah@gmail.com 


\section{PENDAHULUAN}

Peristiwa pemilihan presiden dan wakil presiden merupakan salah satu pesta demokrasi yang ada di Indonesia. Banyak media massa khususnya media cetak yang menyorot peristiwa itu sebagai pemberitan headline di surat kabar mereka. Sikap media tersebut merupakan ara pandangan media dalam memberi ruang sistem demokrasi yang lebih berkualitas. Kerangka atau jalan pemikiran media cetak acapkali melihat sisi tertentu aspek kelompoknya dibandingkan dengan ciri unik pada diri seseorang yang hendak dilaporkan. Bergulirnya dinamika politik yang makin bertambah luas dan komplek menghubungkan antara peristiwa dengan peristiwa lainnya, antara seseorang dengan orang lain.

Dengan pesatnya perkembangan media itu tidak dapat dipungkiri lagi bahwa surat kabar itu telah tumbuh dengan terbitnya lagi surat kabar diantaranya haluan riau, metro riau, media riau, pekanbaru pos, pekanbaru MX dan sebagainya. Semua itu tidak terlepas dari peran dan fungsi pers dengan memproduksi suatu informasi kepada khalayaknya. Produk jurnalis itu tampil dalam bentuk karya tulis yang beraneka ragam, maupun versi dari realitas yang sama dengan pengkonstruksiannya. Kemampuan media mengkontruksi realitas dengan menonjolkan sisi-sisi atau aspek tertentu di dalam karya tulis jurnalis yang dikemas untuk dikomsumsi khalayak pembaca. Riau Pos dan Tribun Pekanbaru merupakan surat kabar terbesar yang telah terbit memberi sumbangsih realitas atas peristiwa politik yang akan disajikannya.

Dinamika politik tersebut terus bergulir hingga berbagai persoalan yang berkaitan dengan para pelaku politik di Indonesia. Para Pelaku politik tersebut antara lain selaku pimpinan negara dari masa ke masa, seperti Megawati (Mega) - Prabowo Subianto, Susilo Bambang Yudhoyono (SBY) - Boediono, dan M. Yusuf Kalla - Wiranto pada masa Pemilihan Presiden dan Wakil Presiden Tahun 2009 yang silam. Berkaitan dengan para pelaku kandidat politik tersebut, publik kerap memperoleh informasi secara luas dan terbuka seiring dengan besarnya rasa keingintahuan publik terhadap berbagai macam informasi politik dalam negeri yang terjadi pada masa itu.

Pada masa pemerintahan Presiden Susilo Bambang Yudhoyono dan Wakil Presiden M.
Yusuf Kalla dengan terbukanya ruang informasi publik pada saat itu. Dengan adanya jaminan sistem demokrasi yang demikian itulah, maka kesejahteraan dan keadilan dapat diwujudkan dengan sebaik-baiknya. Di samping hal tersebut, dengan kebebasan pers yang diselenggarakan oleh media massa secara berkala dan juga untuk memberi kesempatan kepada rakyat, baik mereka yang mengkonsumsi beraneka ragam informasi untuk turut menentukan jalannya proses kebijakan kenegaraan dan pemerintah pada saat itu.

Media massa secara aktif melaporkan liputan politiknya memberi dampak yang amat signifikan memberi perkembangan pendidikan politik di masa depan. Semasa pemilihan presiden dan wakil presiden 2009 yang lalu ditandai dengan kebebasan berdemokrasi di Indonesia, dinamika politik itu mengalami perkembangan pers yang begitu signifikan. Keterbukaan ruang kritik itu ditandai dengan wujud nyata dari perkembangan dinamika politik yang ada di Indonesia terhadap kebijakan politik pada saat itu. Pemikiran itu dapat distereotipkan atau dikategorikan dalam sebuah alur cerita dalam pemberitaan politiknya. Dapat dilihat dengan menyusun, mengungkap, mengisahkan, maupun menekankan kepada realitas politik yang luas dan kompleks. Mudah ditafsirkan oleh semua pihak dengan skema atau pemikiran dalam diri jurnalis atas suatu permasalahan atas suatu realitas membentuk gagasan, pendapat ataupun ide-ide dalam menggunakan simbol, perangkat kode-kode, maupun lambang dalam kemasan berita politiknya (Eriyanto, 2001: viixiv; dan 2002: 85-89). Rangkaian berita politik itu dikemas melalui pemikiran jurnalis dalam bentuk skema berita tertentu. Mengandung daya tarik dan ide-ide penulisan berita atas dasar fakta-fakta dalam arti "reality". Bahkan dapat jadi produk itu merupakan hasil interaksi simbolik antara jurnalis dengan reality fakta yang telah diperoleh dilapangan.

Realitas sosial itu dipahami, dimaknai, dengan merekonstruksi makna atas fakta melalui bentuk bingkai beritanya. Realitas sosial tersebut bukan hanya dipahami sebagai bagian teknis penulisan jurnalistik, melainkan menandakan bagaimana peristiwa dimaknai dan ditampilkan. Inilah sesungguhnya sebuah realitas politik, bagaimana media membangun, menyuguhkan, mempertahankan, dan mereproduksi, suatu peristiwa kepada publik (Eriyanto, 2002: vi). 
Dalam proses penulisan berita komunikasi politik secara penulisan berita dapat ditentukan dengan menentukan struktur organisasinya oleh media massa. Dengan langkah pertama, proses pembuatan itu darimana berita politik direkonstruksi mulai dari media menuliskan fakta dan diterbitkan. Lalu yang menjadi pertanyaan "cerita berita politik itu bertutur tentang apa?" menjadi langkah kedua, dalam menjelaskan beberapa tema sentral dalam simbol dalam proses penulisan berita, perangkat dengan analisis data, maupun lambang bahasa yang digunakan dalam berita politik.

Kemampuan seorang jurnalis dalam menggambarkan realitas politik lengkap dengan aspek-aspek tertentu. Menimbulkan implikasi terhadap berbagai bidang seperti ideologis, politik, ekonomi, budaya, hukum, dan seterusnya. Dengan pengalaman yang dimilikinya belum tentu dinamika politik memiliki arti penting sebagai agenda publik. Karena pengalaman dan pengetahuan publik "melek media" terhadap suatu realitas yang akan ditampilkan belum rata kesemua lapisan masyarakat. Liputan politik itu sesuai dengan perkembangan pers yang menampilkan realitas, berkemungkinan realitas politik itu akan ditampilkan atau tidak ditampilkan dalam proses produksi media massa.

Untuk menganalisis data penelitian, peneliti menggunakan analisis data dengan perangkat analisis framing berdasarkan model milik Zhongdang Pan dan Gerald M. Kosciki. Kendati sistem bahasa dan komunikasi politik yang digunakan komunikator politik mempengaruhi persepsi massa pendukung politik dalam memperebutkan simpati politik yang dilakukan oleh media massa sebagai dengan menghubungkan konteks situasi politik kenyataan pada realitas sosial yang diangkatnya dalam bentuk bahasa politik yang bermakna ideologi tertentu. Dalam memproses produksi bahasa politik itu dapat jadi asumsi pengkonstruksian realitas politik mencerminkan faktor-faktor dalam upaya pembentukan opini publik bermakna komunikasi bahasa politik.

Pandangan Peter L. Berger dan Thomas Luckmann tentang konstruksi sosial atas realitas yang diungkapnya. Beliau menggungkap sesuai dengan alasan Berger adalah "manusia dan masyarakat adalah produk dialektis, dinamis, dan plural secara terus-menerus. Masyarakat tidak lain adalah produk manusia itu sendiri, namun secara terus-menerus mempunyai aksi kembali terhadap penghasilannya. Sebaliknya manusia adalah hasil dari produk masyarakat mengandung ideology tertentu. Seseorang baru menjadi seorang berpribadian yang berindentitas sejauh ia tetap tinggal di dalam masyarakat atau lingkungannya (dalam Eriyanto, 2002: 13-14).

Proses produk dialektis melalui bahasa politik (politics language) ada dua definisi menurut Barelson dan Stainer (1964) yakni communicationis the transmission of information, ideas, emotions, skill, etc. by the use of symbols, pictures, grapds, etc. sementara Gerbner (1964) mendefinisikan communication is social interaction through symbols and massage system (dalam Cangara, 2009: 19). Jika menyimak kandungan makna (politics language) yang terdapat dalam setiap definsi komunikasi yang telah dikemukakan, dapat menemukan adanya sejumlah unsurunsur komunikasi yaitu; sumber, pesan, media, penerima, pengaruh, tanggapan balik, dan lingkungan (Cangara, 2009: 20-23).

Dengan faktor-faktoritu dapat jadi asumsi mewacanakan realitas politik mencerminkan upaya pembentukan opini publik bermakna komunikasi bahasa politik yang dinamis, plural secara terus menerus dalam proses komunikasi itu terjadi dalam anggota masyarakat secara terus menerus pula,sehingga sedikit banyak mempengaruhi sikap dan tingkah laku pihak yang dituju dalam hal ini adalah komunikator politik dan media massa sebagai pengguna bahasa politik (politics language).

Sehingga proses dialektis dalam menggunakan bahasa politik (politics language) perlu pengetahuan dan pengalaman yang dapat dipahami sebagai proses produk dialektis, dinamis, dan plural di masyarakat sosial yang dapat dinikmati, sebagai kekuatan (power) dalam lingkungan secara berkelanjutan countineu yang dilakukan secara bersama (serempak) dimanapun kapan pun.

Fokus tinjauan kepustakaan ini terhubung denganorientasi "ideology" sebagai kekuatan (power) dalam lingkungan secara berkelanjutan countineu yang dilakukan secara bersama (serempak), dimanapun kapan pun dengan yang menitikberatkan hubungan komunikasi langsung atau tatap muka, dengan media massa atau komunikasi massa mengunakan teknologi komunikasi media cetak.

Menurut Pan dan Kosicki dalam Eriyanto 
(2002: 251) tidak melihat teks berita sebagai suatu studi pesan politik yang hadir begitu saja seperti yang ada dalam analisis isi tradisional. Dalam kehadiran teks berita itu disusun berdasarkan formasi dan struktur tertentuatas pandangan, ideas, gagasan, pendapat dari komunikator politik dalam menggunakan bahasa politik (politics language) sebagai kebijakan politik yang akan diambil, namun bahasa politik melibatkan proses produksi dan konsumsi dari suatu teks yang disajikan keranah komunikan (pembaca) target komunikasinya.

Senada dengan Budiardjo (2002) dalam menggunakan bahasa politik (politics language) sebagai kebijakan politik mengatakan politik adalah kegiatan yang dilakukan dalam suatu Negara yang terkait dengan proses menemukan tujuan dan melaksanakan tujuan dari kebijakan umum (public policy) yang mengatur sumber daya yang ada untuk kepentingan seluruh masyarakat. Dimensi politik dalam hubungan antar Negara dengan masyarakat. Dalam hal ini pertama, politik sebagai studi kelembagaan (institution stadies). Kedua, politik sebagai studi kekuasaan (power stadies), dan Ketiga, politik sebagai studi kebijakan publik (public policy stadies) (Cangara, 2009: 29-32).

Studi media massa pada umumnya, khususnya media cetak menggunakan bahasa politik mengenai kebijakan umum dalam ilmu politik sebagai studi politik (political studies). Dalam proses studi itu memerlukan pengetahuan dan pengalaman seseorang, dalam menggunakan skema teks berita mempunyai tujuan untuk mengorganisir pengetahuan, memancing pengalaman dan memori masa lalu untuk melihat dunia sekarang dan memprediksi dunia masa depan. Berdasarkan peristiwaperistiwa yang datang silih berganti tiap hari, dapat menggunakan kerangka berfikir tertentu: karena pandangan ini mirip dengan skenario yang ditulis untuk meletakkan setiap kejadian dan fenomena dalam alur cerita (Eriyanto, 2002: 85).

Dalam Eriyanto (2002) juga membagi beberapa skema teks berita itu dapat hadir sebagai klasifikasi, skema digunakan oleh individu untuk membuat dunia ini tampak bermakna mudah di mengerti untuk itu, dunia ini digambarkan sebagai sesuatu yang beraturan. Seiring dengan perkembangan psikologi manusia dalam memahami manusia itu sendiri, dengan secara sadar bahwa dunia ini terdiri dari berbagai hal, dan berbagai elemen masyarakat tentang ciri-ciri khas seseorang dalam membentuk kredibilitas diri seorang (communicator politic) sebagai objektifitas pembuat kebijakan publik mengandung nilai latent "ideology".

Kemudian ditambahkan Eriyanto (2002) mengatakan pendapatnya bahwa generalisasi, sebagai elemen utama yang sering digunakan seseorang dalam melihat, memperkirakan, dan mempelajari yang berhubungan dengan generalisasi itu dipakai komunikator politik, dan media massa sebagai penghubung lingkungan yang dilukiskan atas fenomena komunikasi itu dengan melekatkan pada ciri-ciri yang sama. Ideologi merupakan sebuah pengaruh yang paling menyeluh dari semua pengaruh. Ideologi diartikan sebagai gagasan, ide-ide, mekanisme simbolik yang menyediakan kekuatan kohesif yang mempersatukan persepsi masyarakat (public opinion).

Dalam upaya melihat serta mempelajari/ memahami wacana pembentukan opini publik ini, sebagai permainan kata (war of words), sebagai bahasa politik, juga sebagai motif media massa, seringkali surat kabar melakukan tiga objek sekaligus sebagai strategi ideologi, strategi komunikator politik, dan strategi lingkup media massanya (individu, rutinitas media, organisasi media, ekstramedia, sampai dengan tatanan ideologi). Rumusan tersebut dalam objek penelitian ini ditunjukkan dalam tabel 1 .

Kerangka pemikiran ini memperlihatkan objek penelitian dengan orientasi peneliti sebagai berikut: Ideologis, idealis, Politik Praktis, dan Pasar atau Lokasi Daerah distribusi Objek penelitian. Dengan orientasi menentukan komunikasi politik dalam pemahaman dan seleksi media massa dalam memproses sistem bahasa yang digunakan dalam komunikasi politik.

Ibnu Hamad (2004) mengatakan bahwa pertama, menggunakan simbol-simbol politik (politics language). Kedua, melaksanakan strategi pengemasan pesan (Framing Strategies). Ketiga, melakukan fungsi agenda media (agenda setting function). Dan ketiga strategi dalam pembentukan opini publik ini seringkali dipengaruhi oleh faktor internal atas dasar kepentingan media massa tersebut berupa kebijakan redaksional mengenai suatu kepentingan politik tertentu, kepentingan 
pengelola media, relasi media dengan kekuatan politik tertentu, dan faktor eksternal seperti sistem politik yang berlaku, permintaan pasar, dan kekuatan-kekuatan luar lainnya. Faktor inilah yang seringkali menimbulkan kemasan redaksional yang berbeda-beda antara media satu dengan yang lainnya dalam menyampaikan peristiwa politik yang sama.

Tabel 1 Objek Penelitian: Kandidat Politik dan Surat Kabar Berdasarkan Orientasi

\begin{tabular}{|c|c|c|}
\hline Orientasi & Nama Kandidat Politik & $\begin{array}{l}\text { Nama } \\
\text { Koran }\end{array}$ \\
\hline \multirow[t]{4}{*}{ Ideologi } & 1. Megawati (Mega)- & Riau Pos \\
\hline & PrabowoSubianto & \multirow{3}{*}{$\begin{array}{l}\text { Tribun } \\
\text { Pekanbaru }\end{array}$} \\
\hline & $\begin{array}{ll}\text { 2. } & \text { Susilo Bambang } \\
\text { Yudhoyono (SBY)- } \\
\text { Boediono }\end{array}$ & \\
\hline & $\begin{array}{l}\text { 3. M. Yusuf Kalla- } \\
\text { Wiranto }\end{array}$ & \\
\hline \multirow[t]{4}{*}{ Idealis } & 1. Megawati (Mega)- & \multirow{4}{*}{$\begin{array}{l}\text { Riau Pos } \\
\text { Tribun } \\
\text { Pekanbaru }\end{array}$} \\
\hline & Prabowo Subianto & \\
\hline & $\begin{array}{ll}\text { 2. } & \text { Susilo Bambang } \\
\text { Yudhoyono (SBY)- } \\
\text { Boediono }\end{array}$ & \\
\hline & $\begin{array}{l}\text { 3. M. Yusuf Kalla- } \\
\text { Wiranto }\end{array}$ & \\
\hline \multirow{4}{*}{$\begin{array}{l}\text { Politik } \\
\text { Praktis }\end{array}$} & 1. Megawati (Mega)- & Riau Pos \\
\hline & ubianto & \multirow{3}{*}{$\begin{array}{l}\text { Tribun } \\
\text { Pekanbaru }\end{array}$} \\
\hline & $\begin{array}{l}\text { 2. Susilo Bambang } \\
\text { Yudhoyono (SBY)- } \\
\text { Boediono }\end{array}$ & \\
\hline & $\begin{array}{l}\text { 3. M. Yusuf Kalla- } \\
\text { Wiranto }\end{array}$ & \\
\hline \multirow{4}{*}{$\begin{array}{l}\text { Pasar atau } \\
\text { Lokasi } \\
\text { Daerah }\end{array}$} & 1. Megawati (Mega)- & Riau Pos \\
\hline & Prabowo Subianto & \multirow{3}{*}{$\begin{array}{l}\text { Tribun } \\
\text { Pekanbaru }\end{array}$} \\
\hline & $\begin{array}{ll}\text { 2. } & \text { Susilo Bambang } \\
\text { Yudhoyono (SBY)- } \\
\text { Boediono }\end{array}$ & \\
\hline & $\begin{array}{l}\text { 3. M. Yusuf Kalla- } \\
\text { Wiranto }\end{array}$ & \\
\hline
\end{tabular}

Sumber: Diolah dari Penelitian Berdasarkan Orientasi Objek Penelitian Pada Harian Riau Pos dan Tribun Pekanbaru

Komunikasi politik inilah yang seringkali menimbulkan kemasan redaksional bahasa politik yang yang dipakai berbeda-beda, media massa satu dengan yang lainnya dalam menyampaikan bahasa politik itu.Ketika media massa mewacanakan dalam bentuk bahasa politik, memiliki makna ideologi yang akan diinformasi atas realitas (kenyataan) yang diterimanya (John Fiske, 2007: 228-258; M. Edy Susilo 2000: 19-20; Eriyanto, 2002: 254; dan Alex Sobur, 2001: 138-139).

\section{METODE PENELITIAN}

Pada dasarnya, dalam mewacanakan peristiwa tertentu yang akan disajikan media massa adalah akumulasi dari pengaruh yang beragam, dengan level media massa dalam mempengaruhi perilaku manusia atau pergeseran perilaku (shifting attitudes). Pamela J. Shoemaker dan Stephen D. Reese (1996) mengemukakan lima level media massa dapat memengaruhi pengambilan keputusan publik agenda setting (dalam Sobur, 2001: 138), yaitu: level individu, level rutinitas media, level organisasi media, level ekstramedia, dan level ideologi.

Komunikasi politik lazim dikaitkan dengan pembicaraan politik atau penyampaian pesan politik verbal maupun non verbal yang dapat mempengaruhi rakyat maupun pemerintah dalam suatu sistem politik. Atau secara sederhana dapat disebutkan bahwa komunikasi politik adalah penyampaian pesan yang bermuatan politik dari suatu sumber kepada penerima untuk menciptakan pemahaman makna bersama (Eko Harry Susanto, 2013). Mengingat komunikasi melekat pada setiap orang sebagaimana, menurut Bower dan Bradac, (1982: 3), "manusia adalah mahluk yang tidak bisa tidak berkomunikasi", maka setiap tingkah laku manusia, termasuk pada saat diam, dan tidak merespon pesan politik dari suatu sumber, tetap saja menimbulkan makna yang berhubungan dengan nuansa politik (dalam Susanto, 2013).

Penelitian ini menggunakan metode penelitian kualitatif dengan kajian secara deskripsi atau analisis terhadap fenomena komunikasi yang tidak tergantung pada pengukuran variabel, akan tetapi penelitan memusatkan pada penganalisaanpada makna ideology yang akan disampaikan atau tidak, kecenderungan analisis dalam upaya atau usaha untuk faktor-faktor yang mempengaruhi "ideology" dengan menginterpretasikan data menguatkan penelitian yang ada, serta menganalisis objek yang akan diteliti dengan 
merujuk pada kajian-kajian riset yang menghasilkan data kualitatif(Fiske, 2007: 280).

Peneliti memfokuskan analisis dengan konteks yang akan diteliti, yaitu memusatkan pada konteks bagaimana wartawan menyusun, mengungkap, mengisahkan, dan menekankan dalam mengkontruksi suatu realitas atas peristiwa tertentu yang berkembang dimasyarakat, tanpa mengkajinya dengan bantuan matematika atau statistik dengan kata istilah lainnya sejauhmana (Fiske, 20007: 280). Peneliti juga akan menunjukan makna strategi mewacanakan itu untuk menyakinkan khalayak pembaca bahwa berita yang dituliskan adalah benar.

Pada subjek ini peneliti mengambil beberapa wartawan tetap yang rutin mengelola media massa dengan wawancara mendalam (depht interview) wartawan media massa sesuai dengan tujuan penelitian ini. Sedangkan yang menjadi objek di dalam penelitian ini adalah pemberitaan (teks naskah) politik Susilo Bambang Yudhoyono(SBY), Megawati(Mega), dan M. Yusuf Kalla yang pernah dimuat di Riau Pos dan harian Tribun Pekanbaru. Mulai proses menyusun, mengungkap, mengisahkan, dan menekankan persitiwa mencerminkan suatu realitas atas persoalan isu politik motif, citra, opini publik, dan sebagainya dalam teks naskah Susilo Bambang Yudhoyono (SBY), Megawati (Mega), dan M. Yusuf Kalla. Yang sebelumnya terbit melalui "Riau Pos dan Tribun Pekanbaru" dan dijadikan wacana headline yang telah terbit dalam wujud teks naskah berita politik pemilihan presiden dan wakil presiden dalam pemilihan umum. Dari pilihan teks naskah berita itu peneliti mengambil beberapa edisi mulai edisi tanggal 25 Mei sampai 9 Juli 2009 sebanyak 10 (sepuluh) edisi berita pemilihan presiden dan wakil presiden pada masingmasing surat kabar yang telah terbit.

Kecenderungan wartawan memahami peristiwa diamati dari keempat elemen struktur makna media massa. Ketika menuliskan berita dan menekankan makna atas peristiwa tertentu, wartawan akan memaknai strategi mewacanakan untuk menyakinkan khalayak pembaca bahwa berita yang dituliskan adalah benar. Pendekatan studi pesan politik ini dapat digambarkan dalam bentuk skema perangkat framing kemudian diambil implikasi dalam tujuan penelitian ini (Eriyanto, 2002: 256).

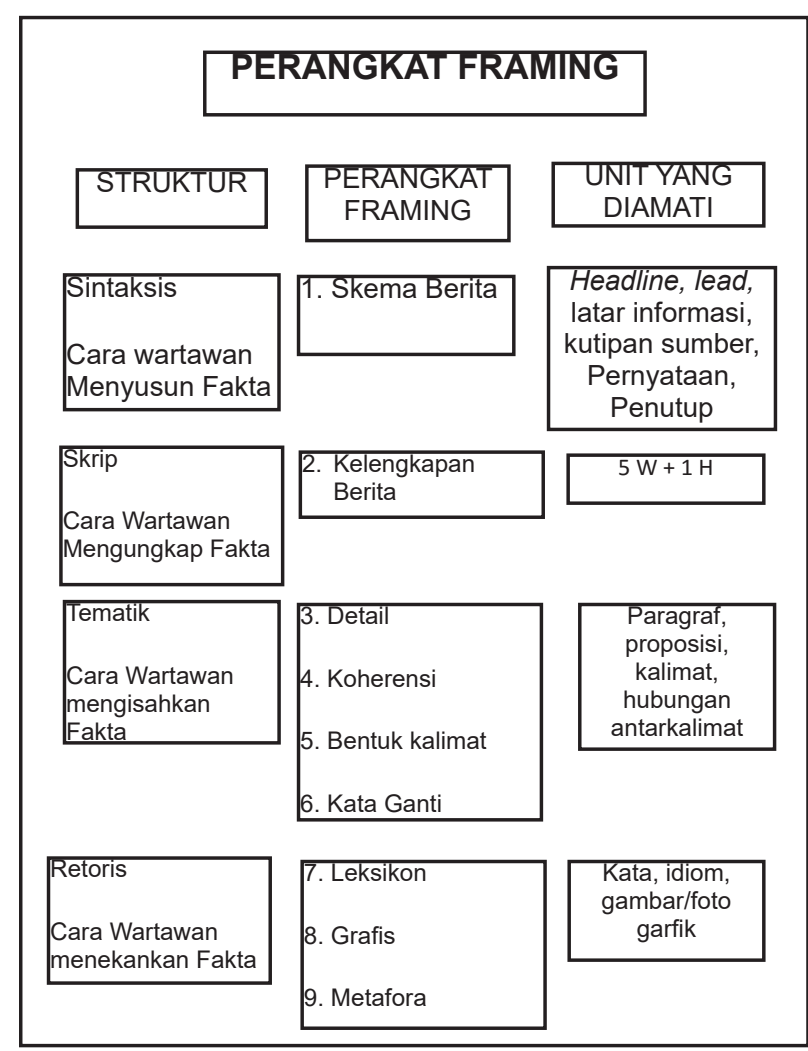

Gambar 1 Perangkat Framing

Pendekatan model analisis Zhongdang Pan dan Gerald M. Kosicki dapat digunakan dalam menganalisis teks naskah politik dalam berita media massa, secara sistematis sebagai berikut: "pertama, teks naskah berita terdiri dari berbagai simbol atau seperangkat kode yang membutuhkan interpretasi sesuai dengan tujuan penelitian. Makna karenanya, tidak dimaknai sebagai sesuatu yang dapat diidentifikasi dengan menggunakan ukuran yang objektif, yang akan dikonstruksi dalam memori khalayak atau peneliti. Kedua, teks naskah media massa ini dilihat sebagai teks yang dibentuk lewat struktur dan formasi tertentu oleh pandangan tertentu, melibatkan proses produksi dan konsumsi dari suatu teks naskah berita politik. Ketiga, Bagaimana teks naskah berita media massa menyimpan kode-kode yang dapat ditafsirkan dengan jalan tertentu oleh peneliti. Ini mengandaikan tidak ada ukuran yang valid, karena tergantung pada bagaimana seseorang menafsirkan studi pesan teks naskah tersebut" (dalam Eriyanto, 2002: 251-252).

\section{HASIL DAN PEMBAHASAN}

Surat kabar Riau Pos merupakan surat kabar tertua yang terbit di Riau. Riau Pos berdiri pada 
18 Januari 1991 di Pekanbaru, dan sebenarnya pada tahun 1989 Riau Pos telah hadir, namun dalam bentuk mingguan diterbitkan oleh yayasan Riau Makmur yang berafiliasi pada Pemerintah Provinsi Riau.

Pada tahun 1987, surat kabar Riau Pos pada awalnya merupakan surat kabar mingguan dengan nama Warta Karya. Sebuah informasi yang merupakan media informasi berfungsi sebagai surat kabar yang representative bagai para insane pers untuk sebuah media lokal yang ada di Riau. Pada waktu pemerintahan Imam Munandar selaku gubernur Riau pada masa itu memberikan izin pendirian Yayasan Penerbitan dan Percetakan dengan nama Riau Makmur.

Kemudian pada tanggal 28 Desember 1988, Yayasan Riau Makmur mmperoleh Surat Izin Usaha Penerbitan (SIUP) pada tahun 1989 untuk menerbitkan surat kabar mingguan dengan nama Riau Pos. Nama Riau Pos berasal dari nama Koran yang pernah terbit di Pekanbaru sekitar tahun 1959-1961, serta atas seizing seorang pejuang 1945, yaitu Letkol TNI (pur.) Hasan Basri selaku pemilih Koran yang bernama Riau Pos terebut.

Kemudian pada tanggal 23 Juli 1990 di Pekanbaru, PT. Jawa Pos memberi kuasa pada Indra Slamet Santoso dan Ridar K. Liamsi dan dari penerbit pada saat itu adalah Yayasan Riau Makmur memberi kuasa kepada Zuhdi, SH, H. Abdul Kadir MZ, dan Asparaini Rasyad dengan melakukan perundingan saham. Perundingan saham tersebut tercetusnya secara bersama mengenai perbandingan komposisi saham PT. Riau Pos yang akan didirikan, yaitu yayasan Riau Makmur 65\%, dan PT. Jawa Pos 35\%. Dalam perundingan menyepakati beberapa posisi jabatan strategis untuk PT. Jawa Pos mengisi jabatan yang ada di Riau Pos, yaitu Komisaris Utama dipegang oleh Eric Samola, Komisaris dipegang oleh Trianto, Direktur Utama dipegang oleh Dahlan Iskan, dan posisi Direktur dipegang oleh Rida K. Liamsi. Kemudian di sisi lainnya, Yayasan Riau Makmur mendapat 3 (tiga) posisi jabatan, yaitu posisi Komisaris dipegang oleh H. Abdul Kadir MZ, Komisaris dipegang oleh Drs. Aparaini Rasyad, dan posisi Direktur dipegang oleh Umar Umaiyah (Wawancara Redaksi). Kesepakatan itu juga memberi tanggung jawab kepada Rida K. Liamsi. Direktur Utama PT. Riau Pos yang dipegang oleh Dahlan Iskan menetapkan Rida K. Liamsi sebagai penanggung jawab redaksi harian Riau Pos, sekaligus penanggung jawab keuangan. Dengan frekuensi penerbitan dengan SIUP hanya mengizinkan terbit sebanyak 4 (empat) kali seminggu dalam bentuk harian Koran (Sumber: wawancara dengan staf redaksi).

SuratkabarRiau Pospada awalnyaberfungsi mempublikasikan berita pembangunan kepada khalayak ramai di Riau. Seiring dengan pesatnya pembangunan, maka perlu adanya media informasi yang dapat dihandalkan untuk merekam dan menyebarluaskan informasi pembangunan secara efektif sekaligus berfungsi untuk kontrol sosial, baik antara Pemerintah dengan masyarakat, ataupun masyarakat dengan masyarakat yang lain. Maka pengelolaan surat kabar Riau Pos mingguan Riau Pos yang profesionali sangat mendesak untuk segera diwujudkan di Provinsi Riau. Sementara saat itu Provinsi Riau hanya mengimpor surat kabar terbitan ibukota atau daerah lainnya. Hadirnya surat kabar Riau Pos disambut oleh masyarakat Riau yang sudah lama menginginkan sumber informasi tentang perkembangan daerah sendiri.

Pada tahap perkembangannya, Riau Pos terus meningkatkan sirkulasinya di setiap daerah yang ada di Riau dengan menerapkan penerbitan Sistem Cetak Jarak Jauh (SCJJ) yang terletak di Tanjung Pinang dalam bentuk halaman Koran.Pada tahun keenam dan ketujuh Riau Pos telah terbit dengan tampilan halaman muka full color setiap harinya dapat menembus angka hingga 25.000 eksemplar. Tahun kedelapan tepatnya pada tahun 1998 Riau Pos mencetak kembali sebanyak 50.000 eksemplar korannya. Dari setiap eksemplar surat kabar yang telah diterbitkan bertahan selama 10 tahun dengan jumlah 35.000 eksemplar setiap bulannya (wawancara Staf Pemasaran).

Pesatnya perkembangan Riau Pos dari tahun ke tahun membawa Riau Pos Group (RPG) menjadi sebuah media Group yang maju dan besar di Provinsi Riau. Riau Pos memiliki visi "menjadi perusahaan multimedia terdepan dan terkemuka di Sumatera", misi "Ikut serta mencerdaskan kehidupan berbangsa, serta motto "bangun negeri bijakan bangsa".

Pada tanggal 18 April 2007 PT. Riau Media Grafika dari kelompok Kompas Gramedia kembali meluncurkan surat kabar baru di Riau, dengan nama surat kabar harian Tribun Pekanbaru. Harian Tribun Pekanbaru adalah surat kabar termuda dan terbesar yang telah terbit 
di Provinsi Riau. Dengan rekrutmen jurnalis yang professional di bidangnya. Penampilan harian Tribun Pekanbaru memberi dampak yang sangat signifikan dalam perkembangan pembangunan di Riau (Staf Redaksi).

Menurut staf redaksi pada harian Tribun pekanbaru berkedudukan di Pekanbaru, karena harian Tribun Pekanbaru itu merupakan kelompok Kompas Gramedia. Dengan motto "Spirit Baru Riau" dengan pemimpin umumnya H. Herman Darmo. Dengan penerbit PT. Riau Media Grafika. Harian Tribun Pekanbaru kelompok Kompas Gramedia adalah surat kabar yang lahir ditengah era reformasi. Dalam perubahan yang melanda hampir beritaberita umum, ekonomi dan bisnis, seputar Pekanbaru, Kepulauan Riau dan Siak, Rengat, dan Bangkinang, serta liputan sport, info artikel life style, dan info selebritis, essy wreding dan friendly adalah kunci. Bertumpu pada keyakinan bahwa kedekatan dengan publik pembaca adalah segalanya bagi surat kabar ini. Upaya yang jelas tidak mudah, namun puji Tuhan, kami berhasil menggapainya. Berangkat dari Indenpendent, friendly, infossible, essy wreding, educating, dift, difrends, credible tersebut, memilih surat kabar untuk sarana promosi menjadi lebih mudah. Memang dibutuhkan perencanaan media yang matang dan efektif agar setiap manajeman marketing yang dikeluarkan mengenai sasaran (wawancara dengan staf redaksi).

Tribun Pekanbaru kelompok Kompas Gramedia layak menjadi pilihan utama karena memilih riset yang representatif, sesuai dengan segmen pembaca, siapa dan bagaimana pembaca Koran Tribun Pekanbaru Cabang Kompas. Dengan data-data yang tertera, anda dapat memahami bahwa surat kabar Tribun Pekanbaru benar-benar memiliki karakter spesifik sebuah media Riau. Terdapat data penyebaran Tribun Pekanbaru kelompok Kompas Gramedia keseluruh pelosok daerah Riau bahkan kepulauan Riau berikut dengan oplah hariannya.

Setelah sukses mengembrak pasar Kota Batam dengan Harian Tribun Batam pada bulan April 2007 lalu PT. Riau Media Grafika dari kelompok kompas gramedia kembali meluncurkan Koran baru di bumi lancang kuning Riau dengan nama Tribun Pekanbaru. Kami hadir di sini ini sebenarnya menawarkan banyak hal yang baru namun yang pasti satu yang kita catat bersama adalah kami membawa
Spirit Baru Riau. Memasuki pasar Riau dibawah bendera PT Riau media grafika sebagai penerbit Tribun Pekanbaru dengan melakukan persiapan yang matang dan terencana. Setelah melakukan riset dalam waktu yang cukup panjang dipengujung tahun 2006 rekrumen SDM mulai dilakukan.

Selanjutnya di awal tahun 2007 SDM terpilih sudah masuk dapur pelatihan intensif selama tiga bulan, dengan prinsip-prinsip cover book size atau berita berimbang, independent, dan kredibel adalah hal-hal yang paling ditekankan dalam pelatihan. Dalam sikap Independent, dan kredibel kami juga menekankan suatu sikap bahwa sebuah berita harus dipandang dari berbagai sisi caver book size orang mengatakan bahkan sekarang kami mencoba mengembangkan namanya cover book all. Jadi kami melihat suatu persoalan tidak dilihat dari satu sisi atau dari satu narasumber saja tetapi berbagai narasumber yang terkait dalam persoalan tersebut. Itu satu sikap independent kredibel yang terus selalu kami bangun dilingkungan Tribun Pekanbaru. Para wartawanpun selalu dikenalkan pada teori baru jurnalistik essy wreding dan friendly dengan format desain dan layout yang hendy menonjolkan kekuatan visual. Kaitannya adalah dengan tampil independent dan kridebel tentu kami tidak berpihak pada siapapun kepada perorangan golongan lembaga tetapi kami berpihak kepada kebenaran (wawancara dengan staf redaksi).

Selanjutnya PT. Indrafeasda Prima media dari kelompok kompas gramedia kembali meluncurkan Koran baru di bumi lancang kuning Riau dengan nama Harian Tribun Pekanbaru. Kami hadir di sini ini sebenarnya menawarkan banyak hal yang baru namun yang pasti satu yang kita catat bersama adalah kami membawa spirit baru riau. Memasuki pasar Riau dibawah bendera PT. Riau Media Grafika sebagai penerbit Tribun Pekanbaru dengan melakukan persiapan yang matang dan terencana.

Seperti yang diketahui bahwa setiap suatu badan usaha yang bergerak dibidang bisnis tentunya memerlukan biaya, baik itu di awal usahanya maupun setelah usahanya berjalan. Harian Tribun Pekanbaru pada awal berdirinya dana sendiri yaitu berupa aset penjualan koran setiap harinya dan aset dari iklan itulah yang dipakai untuk membiayai gaji karyawan, 
wartawan, ataupun biaya-biaya lainnya.

Seiring dengan perjalanan waktu, Harian Tribun Pekanbaru terus melakukan terobosanterobosan untuk tetap eksis dan memberikan informasi-informasi yang sangat diperlukan oleh masyarakat Riau pada khususnya. Oplah Harian Tribun Pekanbaru terus meningkat setiap tahunnya, dari 50.000 eksemplar pada tahun 2007 dan hampir 68.000 eksemplar pada tahun 2008. Harian Tribun Pekanbaru berhasil meningkatkan oplah dengan hasil total oplah pada tahun 2009 kini 85.000 eksemplar untuk pengembangan oplah Harian Tribun Pekanbaru begitu seterusnya pada tahun berikutnya. Dengan strategi pemasaran dan kualitas isi media yang baik pihak manajemen Harian Tribun Pekanbaru melakukan perbaikan dengan menambah karyawan-karyawan yang memiliki kemampuan jurnalistik skala nasional maupun internasional. Agar oplah tetap naik, pihak manajemen juga menerapkan strategi pemberitaan dan sirkulasi dengan memecah dan menerbitkan media di daerah tersebut.

Seiring dengan perjalanan waktu, harian Tribun Pekanbaru kelompok Kompas Gramedia terus melakukan terobosan-terobosan untuk tetap eksis dan memberikan informasiinformasi dan usaha bisnis yang sangat diperlukan oleh masyarakat Riau. Oplah harian Tribun Pekanbaru kelompok Kompas Gramedia terus meningkat pada tahun 2007, dari 35.000 eksemplar pada bulan April 2007 dan sekitar 50.000 sampai 55.000 eksemplar pada akhir tahun 2007. Harian Tribun Pekanbaru berhasil meningkatkan oplah dengan hasil total oplah pada tahun 2009 kini 85.000 eksemplar untuk pengembangan oplah harian Tribun Pekanbaru begitu seterusnya pada tahun berikutnya. Tetapi oplah bertahan berkisaran 55.000 eksemplar pada akhir tahun 2010. Dengan memberikan pelatihan marketing manajemen pemasaran pada para agen distribusi korannya dan kualitas isi media yang baik pihak manajemen Tribun Pekanbaru kelompok Kompas melakukan rekrutmen wartawan dengan pelatihan khusus dengan teori jurnalistik berbagai sisi "cover book size"orang mengatakan bahkan sekarang kami mencoba mengembangkan namanya "cover book all". Jadi Tribun Pekanbaru melihat suatu persoalan tidak dilihat dari satu sisi atau dari satu narasumber saja tetapi berbagai narasumber yang terkait dalam persoalan tersebut. Itu satu sikap independent kredibel yang terus selalu dibangun dilingkungan Tribun Pekanbaru (wawancara dengan staf pemasaran).

Data analisis pemberitaaan realitas pesan politik dengan menggunakan perangkat analisis framing secara perspektif komunikasi dapat membuktikan penelaahan sistem komunikasi media massa. Proses analisis pemberitaan tersebut memperkirakan subjek dan objek penyelenggaraan pemilihan umum presiden dan wakil presiden Republik Indonesia. Dalam aplikasi sederhana milik Zhongdang Pan dan Gerald M. Kosciki bahwa pemberitaan studi realitas politik komunikasi massa dalam mewacanakan studi pesan realitas politik memberikan multimakna dalam proses kejadian dalam penyelenggaraan pemilihan umum tersebut.

Dengan pemberitaan surat kabar Riau Pos dan Tribun Pekanbaru dalam transmisi informasi menggunakan berbagai teknik jurnalistik yang dikemasnya menjadi pemberitaan politik yang cukup bagus. Namun bukti pemberitaan itu dalam studi realitas politik itu ditemukan dengan multimakna (status quo) atau legistimasi pola komunikasi dalam politik dalam penyelenggaraan komunikasi politik itu.

Dalam struktur perangkat analisis Zhongdang Pan dan Gerald M. Kosciki dilihat, diperkirakan, dan dipelajari aplikasi teori studi pesan politik dalam mewacanakanuntuk membedah teks naskah media massa. Dengan mewacanakan media massa yang mereka gunakan dalam teks naskah berita politik, dengan implikasi temuan penelitian sebagai berikut:

Temuan penelitian 1: Perbandingan frame Riau Pos memperlihatkan acara debat pemilihan presiden dan wakil presiden diperkirakan diterima sepenuhnya. Sebaliknya, frame Tribun Pekanbaru memperlihatkan acara debat pemilihan presiden dan wakil presiden diperkirakan pro-kontra.

Dalam komunikasi politik, sesungguhnya setiap aspek memiliki peran tersendiri, walaupun tetap memiliki hubungan secara langsung ataupun tidak langsung dalam aplikasinya. Lima komponen dalam komunikasi politik tersebut menyangkut (1) komunikator politik, (2) pesan politik (3) media yang digunakan dalam komunikasi politik, (4) khalayak komunikasi politik, dan (5) Akibat yang ditimbulkan dari komunikasi dalam politik. (Nimmo, 2007: 114).

Pemberian label komunikasi dalam 
memperlihatkan makna dalam proses argumentasi, berdasarkan pengalaman dan pengetahuan yang mereka miliki masingmasing memberikan makna dalam lebel otoritas kronologis politik yang terjadi di lapangan. Dengan demikian proses itu dapat dijadikan dalam pemberitaan media tersebut dalam teks beritanya.

Pasangan kandidat tersebut maupun sumber ahli timbul sebagai alasan pro dan tidak setuju proses politik itu ditempatkan saling melengkapi dalam proses suksesi yang setara. Pendapat benar, tidak ditempatkan lebih utama dibanding pendapat lain menyatakan argument itu kontra dengan alasan yang kuat. Sehingga argument politik dalam mewacanakan dipekirakan memberi bukti dan klaim terhadap tema yang benar.

Respon acara debat pasangan kandidat yang mempunyai pandangan berkarakter yang satu menilai benar/baik yang lain menilai tidak benar/tidak baik. Memberikan pandangan strategi penulisannya. Dalam komunikasi politik dalam mewacanakan memiliki argumen politik dalam identifikasi masalah yang dilustrasikan oleh tabel 2 maupun tabel 3.
Sesuai tabel 4, proses dalam tahapan sebagai proses mewacanakan internal media berbeda-beda satu sama lainnya, begitu juga teknik penulisan naskah beritanya. Namun strategi persuasi, mempengaruhi iklan politik dan retorika tidak semata-mata mampu meraih dukungan massa, karena itu harus menggunakan saluran komunikasi "interpersonal", "saluran organisasi”, misalnya partai politik, kelompok kepentingan dan organisasi massa yang memiliki tujuan spesifik. Saluran lain yang sangat potensial untuk menyebarkan pesan politik melalui komunikasi massa untuk menciptakan makna bersama antara media massa dan khalayaknya. (Baran, 2012: 7). Sejalan dengan itu, Biagi (2005: 7), menyatakan "Komunikasi massa dari satu orang atau sekelompok orang melalui perangkat transmiting (medium) untuk audiens besar atau pasar". Tujuannya untuk menyebarkan program dan ideologi supaya lebih dikenal khalayak.

Secara substansial, ideologi adalah pikiran (ideas, gagasan, pendapat, dan sebagainya) yang terorganisir, yakni nilai, orientasi (literasi media) dan kecenderungan yang saling melengkapi hingga membentuk perspektif-

\section{Tabel 2 Analisis Wacana Pengkontruksian Riau Pos Pada Acara Debat Pemilihan Presiden} dan Wakil Presiden

\section{Frame : Acara debat pemilihan presiden dan wakil presiden diterima sepenuhnya Elemen Strategi Penulisan \\ Sintaksis $\quad$ Respon acara debat pasangan kandidat yang menyatakan mengangkat ketiga pasangan kandidat presiden dan wakil presiden. Riau Pos menempatkan pendapat kandidat pada mewacanakan acara debat yang dinilai diawal tulisannya, baru disusul oleh pakar/pengamat dengan menilai perlu adanya harus berkarakter. \\ Skrip Penekanan pada aspek legalitas. Sementara sisi moral, rasa keadilan masyarakat dimasukkan dalam liputan politik. Penekanan pada sikap-sikap kandidat politik. Sementara uraian kandidat mendapat tempat dan pengamat/pakar diuraikan tidak mendapat tempat yang lebih besar, melainkan dalam porsi yang sama.}

Tematik (1) Kronologis acara debat kandidat ada perbaikan pada masing-masing kandidat politik.

(2) Argumentasi kandidat adalah benar dan sesuai dengan gagasan atau pandangan arahan moderator

(3) Pasangan kandidat dalam mewacanakan mempunyai argumentasi yang sama kuat, mempunyai porsi yang sama kuat dalam strategi penulisannya.

(4) Perlu diadakan perbaikan pada acara debat kandidat "berkarakter" menjadi jaminan khusus dalam perang wacana.

Retoris Pemberian label otoritas pengalaman dan pengetahuan pada masing-masing kandidat pada awalnya, dan memberi bukti dan klaim terhadap tema yang akan diambil. 
Tabel 3 Analisis Wacana Pengkontruksian Tribun Pekanbaru Pada Acara Debat Pemilihan Presiden dan Wakil Presiden

Frame : Acara debat pemilihan presiden dan wakil presiden Pro-Kontra

Elemen

Strategi Penulisan

\begin{tabular}{ll}
\hline Sintaksis & Respon acara debat pasangan kandidat yang mempunyai pandangan bertolak \\
& belakang yang satu menilai benar/baik yang lain menilai tidak benar/tidak baik. \\
& Memberikan pandangan pendapat disertai dengan bukti dan alasan yang sama- \\
& sama kuatnya. \\
Skrip & Baik pendapat pasangan kandidat tersebut maupun sumber ahli timbul sebagai \\
alasan pro dan tidak setuju proses politik itu ditempatkan saling melengkapi \\
dalam proses suksesi yang setara. Pendapat benar, tidak ditempatkan lebih utama \\
dibanding pendapat lain menyatakan argument itu kontra dengan alasan yang kuat. \\
Sehingga argument politik dalam mewacanakan dipekirakan pro atau kontra sama- \\
Sama benarnya. \\
(1) Kronologis mewacanakan debat pasangan kandidat politik mengalami \\
Tematik pertikaian makna yang diindikasi menimbulkan pro-kontranya. \\
(2) Argument pasangan kandidat politik sebagai tolak ukur menimbulkan pro- \\
ketoris \\
Penilaian klaim suatu kewajaran terhadap tema acara debat dan otoritas pengalaman \\
dan pengetahuan dari pasangan kandidat politik untuk mendukung gagasan/ \\
pendapatnya.
\end{tabular}

Tabel 4 Proses Tahapan Mewacanakan Pada Internal Media Massa (Riau Pos)

\begin{tabular}{|c|c|c|}
\hline $\begin{array}{l}\text { Media } \\
\text { Massa }\end{array}$ & $\begin{array}{l}\text { Tahap } \\
\text { Naskah }\end{array}$ & Materi depth interviuwdengan wartawan tetap media massa \\
\hline \multirow{5}{*}{ Riau Pos } & \multirow{3}{*}{ Perencanaan } & 1. Tema identifikasi masalah pada headline \\
\hline & & 2. Penempatan berita headline media massa \\
\hline & & 3. Pilihan fakta dengan karakter identifikasi. \\
\hline & Produk & $\begin{array}{l}\text { Strategi penulisan berita itu pilihan fakta diolah dengan skema } \\
\text { dipelajari diterima sepenuhnya sebagai kapasitas yang netral. }\end{array}$ \\
\hline & Penyajian & $\begin{array}{l}\text { Secara seksama memberi penyunting dengan sikap dan cara kerja } \\
\text { yang sangat disarankan dipatuhi strategi penulisan paragraph, } \\
\text { antarkalimat, kalimat, dan kata-kata yang dipergunakan untuk } \\
\text { menekankan gagasan/pendapatnya. }\end{array}$ \\
\hline
\end{tabular}

perspektif ideas cara pandang tertentu yang diungkapkan melalui komunikasi dengan media teknologi dan komunikasi antar pribadi.

Faktor media massa itu selalu melekat dalam informasi politik yang disebarkan oleh komunikator kepada masyarakat untuk mencapai tujuan politik. Simbol juga dapat mengkomunikasikan konsep, gagasan umum, bentuk pemahaman makna yang sederhana, dan mudah dipahami dalam hubungan antara komunikator politik dengan khalayak.

Pencitraan media massa merupakan strategis penulisan media dalam memperoleh keuntungan yang sangat besar, tergantung pada apa yang harus diinformasikan oleh media massa tersebut. 
Tabel 5 Proses Tahapan Mewacanakan Pada Internal Media Massa (Tribun Pekanbaru)

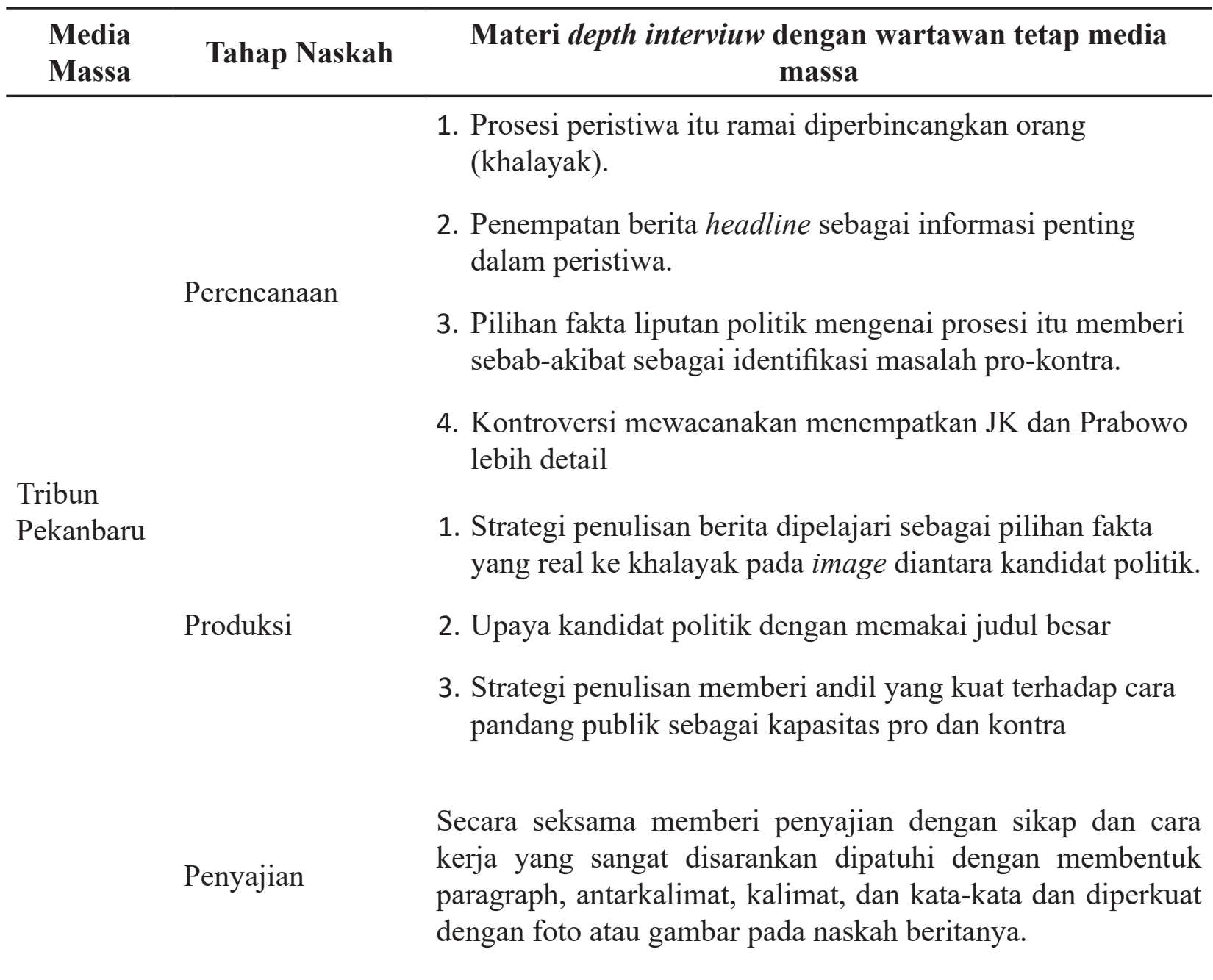

Tabel 6 Publikasi Riau Pos Dan Tribun Pekanbaru Dalam Edisi Judul Per halaman Berita Media Massa dari Tanggal 25 Mei 2009 Sampai Dengan 9 Juli 2009

\begin{tabular}{lccccc}
\hline \multicolumn{1}{c}{ Nama Koran } & $\mathbf{1}$ & $\mathbf{2}$ & $\mathbf{3}$ & $\mathbf{4}$ & $\mathbf{5}$ \\
\hline Riau Pos & 5 & 6 & 4 & - & 15 \\
Tribun Pekanbaru & 3 & 4 & 3 & 1 & 11 \\
Jumlah Publikasi Media Lokal & 8 & 10 & 7 & 1 & 26 \\
Peringkat Publikasi & 2 & 1 & 3 & 4 & Frame \\
\hline
\end{tabular}

Legenda : Jumlah Publikasi Megawati (Mega) - Prabowo Subianto pada kolom pertama; Jumlah Publikasi Susilo Bambang Yudhoyono (SBY) - Boediono pada kolom kedua; Jumlah Publikasi M. Yusuf Kalla - Wirantopada kolom ketiga; dan Jumlah Publikasi Sumber Lokal pada kolom keempat. Serta Total Publikasi pada kolom kelima. 
Tabel 7 Orientasi Surat Kabar dalam Pertarungan Mewacanakan Pasangan Kandidat Politik Terhadap Isu Politik

\begin{tabular}{ccccccc}
\hline \multirow{2}{*}{ Isu Politik } & \multicolumn{6}{c}{ No. Urut \& Nama Pasangan Kandidat Politik } \\
& \multicolumn{7}{c}{ Presiden \& Wakil Presiden } \\
\cline { 2 - 7 } & \multicolumn{2}{c}{ No. Urut 1 } & No. Urut 2 & No. Urut 3 \\
\cline { 2 - 7 } Isu Agama & 1 & 2 & 3 & 4 & 5 & 6 \\
Isu Lokal & $\sqrt{ }$ & - & $\sqrt{ }$ & $\sqrt{ } \sqrt{ }$ & $\sqrt{ }$ & $\sqrt{ } \sqrt{ }$ \\
Isu Meliterisme & - & - & $\sqrt{ }$ & - & $\sqrt{ }$ & - \\
Isu Kapitalisme Pengusaha Kaya & - & $\sqrt{ }$ & - & - & $\sqrt{ }$ & - \\
Isu Kalangan Akademisi & - & - & - & $\sqrt{ }$ & - & - \\
\hline
\end{tabular}

Legenda : Riau Pos $(\sqrt{ })$; Tribun Pekanbaru $(\sqrt{ } \sqrt{ })$; serta nomor urut \& nama pasangan kandidat politik antara Presiden \& Wakil Presiden sesuai dengan nomor 1 dan 2 : Megawati (Mega) - Prabowo; Nomor 3 dan 4 : Susilo Bambang Yudhoyono (SBY) - Boediono; dan Nomor 5 dan 6 : M. Yusuf Kalla - Wiranto.

Tabel 8 Citra Kandidat Politik dalam Surat Kabar Riau Pos dan Tribun Pekanbaru

\begin{tabular}{llll}
\hline \multicolumn{1}{c}{ Nama Koran } & Nomor Urut 1 & Nomor Urut 2 & Nomor Urut 3 \\
\hline Riau Pos & Positif ke Negatif & Positif & Positif \\
Tribun Pekanbaru & Negatif & Negatif ke positif & Positif ke negatif \\
\hline
\end{tabular}

Legenda : Peserta nomor urut \& nama pasangan kandidat politik antara Presiden \& Wakil Presiden sesuai dengan nomor 1 dan 2 : Megawati (Mega) - Prabowo Subianto; Nomor 3 dan 4 : Susilo Bambang Yudhoyono (SBY) - Boediono; dan Nomor 5 dan 6 : M. Yusuf Kalla - Wiranto. Dan Keterangan: + (positif) untuk citra baik; - (negatif) untuk citra buruk; +>- (positif ke negatif) untuk citra baik ke arah buruk; dan ->+ (negatif ke positif) untuk citra buruk ke arah baik.

Tabel 9 Citra Klaim Massa Pendukung Pasangan Kandidat Politik dalam Surat Kabar Riau Pos dan Tribun Pekanbaru

\begin{tabular}{|c|c|c|c|c|c|c|}
\hline \multirow[t]{2}{*}{ Nama Koran } & \multicolumn{2}{|c|}{$\begin{array}{c}1 \\
\text { Sumber Ahli }\end{array}$} & \multicolumn{2}{|c|}{$\begin{array}{c}2 \\
\text { Sumber Ahli }\end{array}$} & \multicolumn{2}{|c|}{$\begin{array}{c}3 \\
\text { Sumber Ahli }\end{array}$} \\
\hline & + & - & + & - & + & - \\
\hline Riau Pos & 2 & 6 & 6 & 1 & 7 & 2 \\
\hline Tribun Pekanbaru & 1 & 3 & 4 & 2 & 3 & 2 \\
\hline $\begin{array}{l}\text { Jumlah Peringkat Makna } \\
\text { komunikator Ahli }\end{array}$ & 3 & 9 & 10 & 3 & 10 & 4 \\
\hline Makna Angka & \multicolumn{2}{|c|}{$\begin{array}{l}(9)+\text { lebih kecil } \\
\text { dari }-(3)\end{array}$} & \multicolumn{2}{|c|}{$\begin{array}{c}(10)+\text { lebih } \\
\text { besar dari }-(3)\end{array}$} & \multicolumn{2}{|c|}{$\begin{array}{c}(10)+\text { lebih } \\
\text { besar dari }-(4)\end{array}$} \\
\hline Legenda & \multicolumn{2}{|c|}{$\begin{array}{l}\text { Positif ke arah } \\
\text { Negatif }\end{array}$} & \multicolumn{2}{|c|}{$\begin{array}{l}\text { Negatif ke arah } \\
\text { Positif }\end{array}$} & \multicolumn{2}{|c|}{$\begin{array}{l}\text { Negatif ke arah } \\
\text { Positif }\end{array}$} \\
\hline
\end{tabular}


Legenda : Sumber ahli massa politik sesuai dengan peserta nomor urut 1 adalah Megawati (Mega) Prabowo Subianto; peserta nomor urut 2 adalah Susilo Bambang Yudhoyono (SBY) - Boediono; dan peserta nomor urut 3 adalah M. Yusuf Kalla - Wiranto.Dengan keterangan: + (positif) untuk citra baik; - (negatif) untuk citra buruk; +>- (positif ke negatif) untuk citra baik ke arah buruk; dan ->+ (negatif ke positif) untuk citra buruk ke arah baik.

Tabel 10 Orientasi Surat Kabar dalam Mewacanakan Kandidat Politik

\begin{tabular}{lll}
\hline \multicolumn{1}{c}{ Orientasi } & Nama Kandidat Politik dalam Pencitraan Politik & Nama Koran \\
\hline Ideologi & 1. Megawati (Mega) - Prabowo Subianto & Riau Pos \\
& 2. Susilo Bambang Yudhoyono (SBY) - Boediono & \\
& 3. M. Yusuf Kalla - Wiranto & \\
Idealis & Susilo Bambang Yudhoyono (SBY) - Boediono & Tribun Pekanbaru \\
Politik Praktis & 1. Susilo Bambang Yudhoyono (SBY) - Boediono & Tribun Pekanbaru \\
& 2. M. Yusuf Kalla - Wiranto & \\
Pasar atau Lokasi & 1. Susilo Bambang Yudhoyono (SBY) - Boediono & Riau Pos \\
Daerah & 2. M. Yusuf Kalla - Wiranto & \\
\hline
\end{tabular}

Legenda : Orientasi media massa politik sesuai dengan pencitraan (citra) peserta nomor urut 1 adalah Megawati (Mega) - Prabowo Subianto; peserta nomor urut 2 adalah Susilo Bambang Yudhoyono (SBY) - Boediono; serta peserta nomor urut 3 adalah M. Yusuf Kalla - Wiranto.Dengan tujuan orientasi koran apakah itu: ideology; idealis; politik praktis; dan pasar atau lokasi daerah.

Tabel 11 Perbandingan Iklim Komunikasi Politik pada Riau Pos dan Tribun Pekanbaru

\begin{tabular}{|c|c|c|}
\hline $\begin{array}{c}\text { Aspek } \\
\text { Komunikasi } \\
\text { Politik } \\
\end{array}$ & Nama Koran & Iklim Komunikasi Politik \\
\hline $\begin{array}{l}\text { Komunikator } \\
\text { Politik }\end{array}$ & $\begin{array}{l}\text { Riau Pos } \\
\text { Tribun Pekanbaru }\end{array}$ & $\begin{array}{l}\text { Dinamika politik dalam wacana sumber informasi yang } \\
\text { beragam berbeda-beda menimbulkan frame berbeda-beda } \\
\text { pula }\end{array}$ \\
\hline Pesan Politik & $\begin{array}{l}\text { Riau Pos } \\
\text { Tribun Pekanbaru }\end{array}$ & $\begin{array}{l}\text { Dari isu politik beragam berdasarkan ideology media itu } \\
\text { dalam strategi penulisannya }\end{array}$ \\
\hline $\begin{array}{l}\text { Media } \\
\text { Komunikasi } \\
\text { Politik }\end{array}$ & $\begin{array}{l}\text { Riau Pos } \\
\text { Tribun Pekanbaru }\end{array}$ & $\begin{array}{l}\text { Media massa dalam melihat, diperkirakan, dan mempelajari/ } \\
\text { dipahami bahwa media terpengaruh dengan sumber internal } \\
\text { dan sumber ekternal media dalam menjalankan profesi } \\
\text { jurnalisnya }\end{array}$ \\
\hline $\begin{array}{l}\text { Khalayak } \\
\text { Komunikasi } \\
\text { Politik }\end{array}$ & $\begin{array}{l}\text { Riau Pos } \\
\text { Tribun Pekanbaru }\end{array}$ & $\begin{array}{l}\text { Massa politik sebagai partisipasi politik yang ikut } \\
\text { memeriahkan pesta demokrasi Massa yang "apolitis" } \\
\text { kesadaran ideologis dalam keadaan tertekan bahkan } \\
\text { fanatisme pada salah satu pasangan kandidat politik dengan } \\
\text { kesadaran ideologis yang masih tinggi }\end{array}$ \\
\hline $\begin{array}{l}\text { Efek } \\
\text { Komunikasi } \\
\text { Politik }\end{array}$ & Riau Pos & $\begin{array}{l}\text { Legitimasi kekuasaan politik mengenai pemikiran (ideas, } \\
\text { gagasan, pendapat, dan pandangan), niat (prosedur media } \\
\text { massa), kekuatan (power), dan permodalan dalam marketing } \\
\text { politik (Firmanzah, 2008: } 211 \text { ) }\end{array}$ \\
\hline
\end{tabular}


Komunikatorpolitiktidakdapatmelepaskan diri dari kemampuan dalam mengorganisasikan pesan politik kepada khalayak yang menuntut demokratisasi dalam bernegara, kesejahteraan dan keadilan. Esensi komunikasi politik, khususnya yang berhubungan dengan pengaturan dan penyebaran pesan politik demi mempengaruhi khalayak ataupun calon pemilih. Upaya mempengaruhi partisipasi masyarakat dalam pemilihan umum, bukan pekerjaan mudah, mengingat respon khalayak berbeda-beda tergantung dari karakter yang melekat. Pengaturan pesan dalam komunikasi politik yang menyentuh kebutuhan masyarakat secara mendasar akan meningkatkan partisipasi masyarakat dalam kegiatan politik, khususnya pemilu dan membangun kredibilitas komunikator politik dengan partai politiknya secara positif.

Temuan penelitian 2: Perbandingan frame surat kabar: Riau Pos dan Tribun Pekanbaru akibat frame efek komunikasi politik yang berbeda-beda dalam melihat, dipelajari/dipahami, dan memperkirakan, sebab asumsi mewacanakan terlihat dengan menyusun, mengungkap, mengisahkan, dan menekankan sebagai fakta atas peristiwa (realitas) menimbulkan efek berbeda-beda. Frame Riau Pos dengan elemen framing cenderung memperlihatkan Acara debat pemilihan presiden dan wakil presiden diterima sepenuhnya. Sebaliknya, Tribun Pekanbaru dengan analisa framing dengan acara debat pemilihan presiden dan wakil presiden pro kontra.

Pembahasan temuan: Peristiwa pemilihan presiden dan wakil presiden dalam mewacanakan pada media massa memilih fakta atas peristiwa tersebut cenderung berbeda-beda, karena media massa memiliki elemen tertentu maupun strategi penulisan untuk mewacanakan informasi itu.

Temuan penelitian 3: Dengan mempelajari interaksi simbolikyang digunakan dalam analisa itu cenderung dipahami sebagai kontroversi yang besar, terutama perdebatan antar kandidat politik antara interaksi simbolik yang dilalukan komunikator dan komunikator media sebagai frame surat kabar, diantaranya adalah Riau Pos dengan Tribun Pekanbaru menimbulkan opini publik dengan mewacanakan: Kutipan,
CETAK RIAU POS DAN TRIBUN PEKANBARU

tanggapan, ideas, statement peristiwa pemilihan presiden dan wakil presiden mempunyai kontroversi yang besar, terutama dari sudut perdebatan antarkandidat.

Pembahasan penelitian: Pertama, komunikator dan komunikator media dengan sisi cara pandangan itu juga kontroversial antara kedua media tersebut. Cara pandangan yang satu dengan yang lain berbeda-beda menghadapi proses suksesi itu. Maka kedua, ketika peristiwa politikitu berlangsung memberi dugaan atau asumsi dengan persepsinya masingmasing, ada orang mengatakan setuju dan ada pula yang tidak. Masing-masing peristiwa itu diperkuat dengan dasar pembenar dengan alasan keberpihakannya pada kepentingannya. Ketiga, peristiwa ini menunjukkan bagaimana terjadi perang simbolik (simbolic war) dengan interaksional komunikasi verbal dengan menggunakan bahasa politik antara pihakpihak yang berkepentingan terhadap isu politik (ideologis, edialis, ekonomi, dan kepentingan lokal). Keempat, media massa mempunyai strategi penulisan dalam mewacanakanatas peristiwa kontroversial tersebut. Dengan frame kedua media massa itu menentukan bagaimana fakta diambil, siapa yang diwawancarai, bagaimana hasil wawancara itu diperlakukan, bagaimana ia ditulis dan ditempatkan dalam halaman surat kabar. Dalam identifikasi masalah pencitraan (citra) politik yang ingin disampaikan kepada publik adalah respon kandidat pada pemilihan presiden dan wakil presiden telah memenuhi syarat legal. Pendapat yang setuju memang dimuat oleh Riau Pos, tetapi untuk dikontraskan dengan pendapat yang setuju yang diuraikan dalam detail panjang. Akibatnya, pendapat mereka yang tidak setuju dengan proses suksesi dicitrakan tidak benar atau pendapat minoritas diantara pakar atau pihak lainnya yang setuju maupun tidak setuju dengan proses suksesi dalam acara debat antarkandidat politik.

Temuan penelitian 4: Sementara Tribun Pekanbaru menempatkan pihak-pihak yang tidak setuju dan setuju dengan proses suksesi tersebut dengan tampilan dan detail yang sama. Dengan cara menampilkan fakta demikian, frame citra yang muncul dihadapan khalayak adalah adanya kontroversi di antara para pakar/pihak-pihak, masing-masing dengan 
argument yang sama benarnya. Pihak-pihak yang berpendapat dibiarkan tanpa pemaknaan dari media yang bersangkutan. Dengan membeberkan pihak-pihak yang berdebat dan argumentasinya masing-masing, Tribun Pekanbaru ingin menunjukkan bahwa disanalah kontroversinya.

Pembahasan temuan: Simbol interaksi menyakut efek yang dihasilkan dalam mewacanakan Tribun Pekanbaru adalah peristiwa tersebut mengandung perdebatan tinggi dalam acara debat pemilihan presiden dan wakil presiden, memberi pandangan publik (opini publik) kepada sesuatu peristiwa bahwa "saya yang benar". Dengan demikian frame semacam ini menunjukkan juga bahwa Tribun Pekanbaru tampaknya cukup berhati-hati dalam menilai peristiwa tersebut. Tribun Pekanbaru tidak memilih sisi-sisi kontroversi seperti Riau Pos yang mengambil posisi persetujuan terhadap proses suksesi. Dalam hubungannya dengan kehidupan berbangsa dan bernegara, Bambang Setiawan (1990: 407) berpendapat, "komunikasi politik adalah proses penyampaian pendapat, sikap dan tingkah laku orang-orang, lembagalembaga atau kekuatan-kekuatan politik dalam rangka mempengaruhi pengambilan keputusan politik, sedangkan yang dimaksud dengan politik tidak lain adalah kehidupan bernegara". Secara fleksibel, "komunikasi politik merupakan komunikasi yang mengacu pada kegiatan politik" (Nimmo, 2007: 8). Dengan demikian semua kegiatan bernuansa politis, yang dilakukan oleh pemerintah, atau kekuasaan negara beserta institusi pendukung maupun yang dilakukan (dalam Susanto, E. H., 2013).

Temuan penelitian 5: hasil temuan itu dalam proses mewacanakan acara debat pemilihan presiden dan wakil presiden 2009 itu, pada dasarnya peneliti mengungkapkan langkahlangkah menyederhanakan dan mengumpulkan data-data observasi dilapangan yang diperlukan.

Menurut redaktur kedua media massa, tahap-tahap proses mewacanakan di internal media massa dalam wawancara mendalam (depth interview) dapat digunakan sesuai bentuk perangkat secara sistematis atas teks berita media yang dipakainya. Prosedur itu adalah proses tahapan media massa dalam mewacanakan suatu peristiwa tergantung surat kabarnya, menurut redaktur media massa membagi tiga struktur penting: struktur perencanaan, struktur produk, dan struktur penyutingan media massa. Dalam proses mewacanakan surat kabar Riau Pos maupun Tribun Pekanbaru menimbulkan perbedaan dalam mempersepsikan opini publik pada realitas yang diliputnya. Namun hal ini, sebenarnya adalah prosedur pengelolaan wacana media menjadi teks beritanya. Sehingga dianggap suatu kewajaran dalam menyampaikan pendapat di tengah masyarakat (khalayak pembaca) atau sebagai diskusi publik.

Pembahasan temuan: menurut pandangan Hilgard dan Brower, mengatakan kemampuan intelektual seseorang semakin tinggi intelektual seseorang, semakin mampu orang itu menangkap pesan secara simbolik. Ada alasan mengapa tingkat pendidikan dipengaruhi pada kognisi (cara berfikir) dan pemahaman non verbal. Tingkat pendidikan berkaitan dengan sekolah. Di sekolah diajarkan tentang berbagai budaya di dunia. Di sekolah, kemampuan seseorang untuk memandang dunia world view bertambah. Makin lama seseorang berada di sekolah, semakin luas pemandangan dunianya (dalam Tinambunan, 2002: 44).

Temuan penelitian 6: untuk mengetahui faktor-faktor yang berpengaruh pada pembentukan realitas sosial dalam naskah berita acara debat pemilihan presiden dan wakil presiden 2009 itu terhadap pencitraan politik.

Pembahasan temuan: pertama, dalam pemilihan presiden dan wakil presiden 2009 dapat orientasi bahwa Tribun Pekanbaru dalam mewacanakan pasangan kandidat politik terhadap isu politik, seperti isu agama menggunakan jilbab dengan identifikasi masalah mengenai penggunaan jilbab bagi istri kandidat politik presiden dan wakil presiden pertama yang diberitakan adalah Ani Yudhoyono (SBY) istri Susilo Bambang Yudhoyono (SBY) yang ditempatkan dalam judul berita media menjadi tekanan isu politik tersebut. Sementara yang kedua yang strategi penulisan berita sebenarnya pada pasangan nomor urut satu Megawati (mega) adalah satu-satunya kandidat politik berasal dari kaum hawa atau perempuan yang dalam pemberitaan itu tidak berjilbab, kemudian pasangan kandidat politiknya wakil presiden Prabowo Subianto ialah berstatus duda atau cerai hidup. Strategi penulisan mewacanakan peristiwa penggunaan jilbab yang dituliskan Tribun Pekanbaru untuk identifikasi masalah isu agama/dekat islam maksud penulisannya.

Kedua, Strategi penulisan lainnya 
mengenai isu local/pasar masalah ekonomi daerah Riau Pos dan Tribun Pekanbaru sama-sama mengidentifikasi masalah isu lokal tersebut dengan mewacanakan Susilo Bambang Yudhoyono (SBY) dengan M. Yusuf Kalla sebagai strategi penulisannya dengan memberitakan kandidat politik presiden antara nomor urut dua maupun kandidat politik nomor tiga sebagai pemenang di Riau.

Ketiga, dalam mewacanakan Riau Pos terhadap isu politik, yaitu mewacanakan kandidat politik dengan isu meliterisme. Strategi penulisan Riau Pos menampilkan kandidat politik yang mengikuti pemilihan presiden ini kedalam dua pilihan antara lain, mereka (Prabowo Subianto kandidat wakil presiden nomor urut satu, Susilo Bambang Yudhoyono kandidat presiden nomor urut dua, dan Wiranto kandidat politik wakil presiden nomor urut tiga) sebagai mantan meliter aktif yang harus bersifat netral terhadap kemanunggalan TNI dan Polri yang harus bersifat netral. Kendati identifikasi masalah kedua adalah mereka adalah orang meliter yang cukup disegani dalam kalangan militer (masa orde baru) pada saat itu.

Selanjutnya keempat adalah isu kapitalisme pengusaha kaya dalam mewacanakan Riau Pos adalah Prabowo Subianto (kandidat wakil presiden) dan M. Yusuf Kalla(kandidat presiden) sebagai pengusaha sukses dalam strategi penulisannya. Namun hanya sedikit informasi mengenai identitas sosial kedua kandidat politik tersebut dalam strategi penulisannya. Yang tidak mendapat tempat dalam mewacanakan media Riau Pos adalah Boediono sebagai kandidat wakil presiden nomor urut dua yang merupakan kalangan akademisi yang memiliki ideas dalam menentukan program-programnya.

Temuan penelitian 7: Dalam prosesi komunikasi politik yang dilakukan oleh ketiga pasangan kandidat politik mengkomunikasikan bagaimana suksesi acara debat pemilihan presiden 2009 berjalan dengan lancar.

Pembahasan penelitian: Kendati permasalahan itu komunikator politik dalam acara debat pemilihan presiden dan wakil presiden itu mengalami kesulitan melakukan komunikasi tentang permasalahan pemilihan kata dalam penbicaraan debat pemilihan presiden dan wakil presiden 2009. Namun hal itu dapat dilakukan oleh beberapa pasangan kandidat politik dengan citranya:

Pertama, seperti nomor urut satu adalah
Megawati (Mega)-Prabowo Subianto, nomor urut dua adalah Susilo Bambang Yudhoyono (SBY)-Boediono, dan nomor urut tiga adalah M. Yusuf Kalla-Wiranto dalam citra pasangan kandidat politik dalam surat kabar Riau Pos dan Tribun Pekanbaru. Surat kabar Riau Pos nomor urut satu adalah Megawati (Mega)-Prabowo Subianto dalam mengelola pemberitaan media Riau Pos menghasilkan dengan citra positif ke negative untuk citra baik ke arah buruk. Nomor urut dua adalah Susilo Bambang Yudhoyono (SBY)-Boediono dalam pemberitaannya citra yang ditampilkan positif untuk citra baik. Citra M. Yusuf Kalla-Wiranto dengan nomor urut tiga cenderung dalam pemberitaan Riau Pos menimbulkan citra positif untuk citra baik pula.

Kedua, surat kabar Tribun Pekanbaru mulai dari nomor urut satu adalah Megawati (Mega)Prabowo Subianto bercitra negative untuk untuk citra buruk. Nomor urut dua bercitra negative ke positif untuk citra buruk ke arah baik yang dilakukan oleh Susilo Bambang Yudhoyono (SBY)-Boediono. Nomor urut tiga adalah $\mathrm{M}$. Yusuf Kalla-Wirantocenderung mengalami citra positif ke negative untuk citra baik ke arah buruk.

Ketiga, citra klaim massa pendukung kandidat politik menunjukan bahwa surat kabar Riau Pos dan Tribun Pekanbaru dalam pernyataan dan argumentasi politiknya oleh sumber ahli komunikasi politik menggunakan gagasan atau idea klaim politik, dalam suksesi acara debat pemilihan presiden dan wakil presiden 2009.Mulai dari tanggal 25 mei 2009 sampai dengan 9 juli 2009 yang dikontruksi oleh Riau Pos dan Tribun Pekanbaru. Bahwa sumber ahli komunikasi politik yang dilakukan oleh komunikator politik oleh Megawati (Mega)Prabowo cenderung mendapatkan makna positif ke arah negative untuk citra baik ke arah buruk. Subianto Susilo Bambang Yudhoyono (SBY)Boediono menghasilkan perdebatan dalam acara debat itu dengan mendapat makna negatif ke arah positif untuk citra buruk ke arah baik. Selanjutnya komunikasi politik oleh M. Yusuf Kalla-Wiranto cenderung menghasilkan negatif ke arah positif untuk citra buruk ke arah baik, walaupun dalam perdebatan itu mereka tampak vocal dan bagus dalam acara tersebut.

Temuan penelitian 8: patokan liputan yang dipakai adalah kebijaksanaan readaksi (redactional concept) media masing-masing yang sangat boleh jadi hal itu dipengaruhi 
oleh kepentingan idealis, ideologis, politis dan ekonomis. Tetapi, apapun yang menjadi pertimbangan, yang relatif pasti adalah adanya realitas yang ditonjolkan bahkan dibesar-besarkan, disamarkan, atau bahkan tidak diangkat sama sekali dalam setiap pengkonstruksian realitas.

Pembahasan penelitian: peliputan kedua media surat kabar Riau Pos dan Tribun Pekanbaru cenderung pada aspek faktualitas (ideologis, idealis, politis, dan ekonomis) dalam acara debat pemilihan presiden dan wakil presiden. Meskipun terdapat penekanan pada aspek legalitas isu-isu faktual yang menjadi sorotan publik atas persoalan dan kasus yang terkait pelaku politik di masa pemerintahannya masingmasing. Menggunakan berbagai bentuk istilah dengan menampilkan atribut-atribut metafora teks (kata, frase, kalimat dalam paragrafnya. Kebanyakan tampilan teks berita dipengaruhi dengan ruang lingkup kerja media itu sendiri menunjukkan upaya sosialisasi antarcalon dalam pemilihan presiden dan wakil presiden 2009. Dapat diketahui bahwa pasangan kandidat politik sebagai komunikator politik yang memiliki keistimewaan dalam retorika politik berdasarkan pengalaman dan pengetahuan dalam wacana politik yang disampaikannya. Dengan mewacanakan dan strategi penulisan Riau Pos dan Tribun Pekanbaru menimbulkan iklim komunikasi politik yang "good ideas", karena memberikan cerminan identifikasi masalah komunikasi politik dengan melihat aspek, kemudian diperkirakan, dan selanjutnya dipelajari akan menambah ilmu pengetahuan kepada lapisan masyarakat tentang pendidikan politik yang akan diwacanakan pada masa akan depan.

\section{SIMPULAN}

Berdasarkan temuan-temuan data serta hasil analisa, diperoleh kesimpulan-kesimpulan sebagai berikut: Secara umum, teori komunikasi politik pada penyajian kandidat politik terbatas pada penyajian durasi debat pemilihan presiden dan wakil presiden 2009, dilihat dari sudut pandang ideology, massa partai pendukung, peristiwa seputar debat pemilihan presiden dan wakil presiden 2009, dan pemberian klaimklaim tertentu; belum menyentuh penggambaran dari sudut informasi publik secara menyeluruh terhadap peristiwa politik yang sebenarnya, mulai dari pertama, aktifitas eksternal (external activities) tentang bingkai teks cenderung untuk menggunakan bingkai berbeda adalah peristiwa debat pemilihan presiden yang diperkirakan oleh pilihan konflik di dalam memuat wacana pesan media "pesanan" pada berita medianya. Kedua, aktifitas objek (object activities) kedua,yang dilihat dari tahap teknik adalah menulis teks pada bingkai di dalamperistiwa debat pemilihan presiden, tahap perencanaan berita media, tahap memproduksi berita media, tahap memproses hasil akhir mengedit berita media. Dan ketiga, aktifitas Internal (internal activities) merupakan faktor efek pesan membentuk sistem politik dengan komunikasi yang politis di dalam mewacanakan media pada peristiwa debat pemilihan presiden dan wakil presiden 2009.

Dengan pendekatan kualitatif dalam studi ilmu komunikasi yang digunakan perangkat analisa model Zhongdang Pan and Gerald M. Kosciki menemukan gejala-gejala komunikasi dalam mengkontruksikan kandidat politik media kita menyimpan motif berbeda-beda. Perbedaan motif ini tentu saja tidak mempermasalahkan hitam putih. Kedua media sebut saja Riau Pos dan Tribun Pekanbaru terlibat dengan kontruksi ideologis karena pasar (khalayak pembaca) media itu sebagai nilai Laden secara ideologis. Dalam keadaan demikian, sebuah media massa memanfaatkan sentiment ideologis untuk mempertahankan pasar. Sebaliknya, kontruksi yang bersifat politik praktis, bukan berarti sama sekali tanpa memotivasi ekonomis.

Interaksi Pers dan Prinsipnya, kecenderungan pada motif media massa itu atau orientasi dalam pemberitaan menekankan faktor-faktor internal dan eksternal mana saja (ideologis, idealis) dan faktor eksternal mana saja (pasar, situasi politik) yang lebih berpengaruh terhadap pengkontruksian kandidat politik itu oleh Riau Pos dan Tribun Pekanbaru. Media massa yang dipengaruhi oleh faktor-faktor ideologis adalah Riau Pos; yang dipengaruhi faktor idealis adalah Tribun Pekanbaru. Oleh faktor politis-praktis adalah Koran Tribun Pekanbaru, karena lebih menonjolkan pada aspek pertentangan "past poisoning." Dan yang lebih mempertimbangkan pasar atau ekonomi adalah Riau Pos, karena memberikan lebel atau klaim dukungan massa secara penuh dalam mewacanakan.

Dalam peristiwa debat pemilihan presiden 
2009, faktor ekternal ekonomis (pembaca) disini bisa ditambahkan dengan penambahan oplah iklan terhadap media massa. Dalam masa 2009 itu beberapa peristiwa dalam pemberitaan pemilihan presiden dan wakil presiden 2009 menambah asset iklan politik (kapitalisme media) sebagai industri media besar lokal.

Pilihan fakta dalam pemilihan presiden dan wakil presiden 2009 itu merupakan acara yang dinantikan banyak orang (khalayak pembaca) dalam pemberitaan Riau Pos menunjukan pemilihan presiden dan wakil presiden bahwa, peristiwa berdebat pemilihan tersebut menerima secara penuh. Dengan memberi otoritas pada pengalaman dan pengetahuan tentang mana calon akan (jadi) terpilih? (satu sama lain mendukung) pada peristiwa berdebat pemilihan presiden dari awal sampai akhir pesan media dengan gagasan politiknya, memberi bukti dukungan dan mengakui tiga pasangan calon politis ke dalam tema peristiwa berdebat pemilihan presiden dan wakil presiden 2009 . Pilihan fakta pemberitaan Tribun Pekanbaru menunjukan pilihan fakta yang dipilih, peristiwa berdebat pemilihan presiden adalah pro kontra atau pilihan di posisi tidak mendukung (pilihan konflik). Dengan memberi penilaian mengakui ke debat tema peristiwa dan otoritas pengalaman dan pengetahuan antarcalon untuk mendukung pendapat atau ideanya.

Mengikut semangat budaya politik local di provinsi riau yang digagas dari paradigma kontruksi realitas politik yang dipakai dalam penelitian ini, dapat disimpulkan bahwa pengkontruksian kandidat politik oleh media massa lokal di provinsi riau kita tampaknya belum menopang pada peningkatan kualitas demokrasi dalam menegakkan demokrasi yang bermartabat di bumi lancang kuning ini. Pengkontruksian kandidat politik dalam acara debat pemilihan presiden masih didominasi oleh sisi luarnya. Seharusnya liputan kandidat politik lebih banyak lagi mempertengahkan wacana budaya politik lokal dalam mengaspirasikan kehendak masyarakat kepada kandidat politik. Supaya calon pemilih menjadi tahu duduk apa yang harus dilakukannya terhadap kandidat politik dalam debat politik pemilihan presiden dan wakil presiden. Dengan mengetahui secara benar "frame" sebuah pasangan kandidat politik dalam mengangkat budaya politik local, maka pemilih dapat menggunakan hak pilihnya secara benar dan pilihan rasional.
Dengan menggunakan analisis framing kritis ini, terlebih dahulu lagi dengan mengikuti paradigm kritikal seperti yang dilakukan dalam riset ini, ditemukan bahwa terdapat sejumlah realitas yang tersembunyi atau realitas maya (Vitual reality) di balik (sebuah) teks (discourse) berupa "fakta sosial" pembuat wacana berupa bermacam kepentingan ideologis (politis), ekonomis (pasar), idealis, dan politik praktis. Hal ini mengajarkan bahwa teks adalah hasil bentukan secara sadar atas pertimbanganpertimbangan atau motif-motif ideologis, ekonomis, idealisme, dan politik praktis.

Secara teoritis hal ini memberi implikasi bahwa dalam memahami/mempelajari isi media (jurnalistik) dari aspek teknik belaka jelas tidak memadai lagi. Penjelasan tentang isi media harus menyentuh "fakta-fakta sosial" yang potensial masuk kedalam teks tersebut, baik itu aspek ideologis, politis, ataupun ekonomis. Kepada para peserta diklat jurnalistik tersebut sebaliknya juga diajarkan mengenai "kesadaran berwacana" agar mereka menyadari dengan baik atas karya yang dihasilkannya.

Karena teks itu bisa diamati dengan berbagai macam kepentingan, maka secara praktis kita dapat belajar mengenai strategi pengemasan pesan. Melalui pemakaian simbol dan struktur penyajian, kita dapat menampilkan siapa diri kita di depan publik.

Nilai kepraktisan ini bisa dipergunakan untuk menyusun teks iklan, press release oleh public relations, naskah pidato untuk orator/ juru bicara, pengemasan produk (pemasaran), dan sebagainya. Seharusnya, nilai kepraktisan ini tidak dipakai untuk melakukan kebohongan publik oleh pihak manapun terutama pejabat pemerintah dan swasta, serta media massa.

Hasil riset ini menunjukkan, dalam mewacanakan realitas politik, media massa kita cenderung ke peristiwa (event) ketimbang pada program pasangan kandidat. Ini menandakan bahwa media massa kita belum turut serta secara aktif membangun kualitas kehidupan politik; tetapi masih lebih suka menceritakan struktur luar (kulit ari) dari kejadian yang dilakukan oleh atau yang menimpa sepasang kandidat politik. Namun lebih kepada mengoptimalkan lebih mengedepankan subtansi (program) yang dimiliki masing-masing pasangan kandidat agar publik dapat menilai secara seksama pasangan kandidat pilihannya. Kemampuan media massa menjadi agen (agen bukan lagi semata-mata 
sebagai saluran) akan lebih optimal fungsinya bila diarahkan untuk membentuk opini publik yang sehat tentang realitas masing-masing pasangan kandidat politik.

\section{DAFTAR PUSTAKA}

Baran, S. J. (2012). Pengantar komunikasi massa: melek media dan budaya. Jakarta: Penerbit Erlangga.

Biagi, S. (2005). Media impact: an introduction to mass media. Seventh Edition, United States: Thomson - Wadsworth.

Cangara, Hd. (2009). Komunikasi politik; konsep, teori, dan strategi. (eds.), cetakan pertama. Jakarta: Rajawali Pers.

Eriyanto. (2002). Analisis framing; konstruksi, ideologi, dan politik media.Yogyakarta: LkiS.

----------. (2001). Analisis Wacana; pengantar analisis teks media. Yogyakarta: LkiS.

Firmanzah. 2008. Marketing politik: antara pemahaman dan realitas. Jakarta: Yayasan Obor Indonesia.

Fiske, J. (2007). Cultural and communication studies, sebuah pengantar paling komprehensif. Yosal Iriantara dan Idi Subandy Ibrahim. (eds): cet. IV. Yogyakarta: Jalasutra.

Hamad, I. (2004). Konstruksi Realitas politik dalam media massa; sebuah studi critical discourse analysis terhadap berita-berita politik, Pengantar: Prof. Dr. Harsono Suwardi, MA. Eds. Jakarta: Granit

Nimmo, D. (2007). Political communication and public opinion in America, atau komunikasi politik: komunikator, pesan dan media, Cetakan kedua, terjemahan Tjun Surjaman. Bandung: Remaja Rosda Karya.

Tinambunan, W. E. (2002). Teori-teori komunikasi. Jakarta: Swakarya.

Sobur, A. (2001). Analisis Teks media; suatu pengantar untuk analisis wacana, analisis semiotik, dan analisis framing. Bandung: Remaja Rosdakarya.

Susanto, E. H. (2013). Dinamika Komunikasi Politik dalam Pemilihan Umum. Jurnal Kajian Komunikasi; Volume 1, No. 2, Desember 2013 hlm. 163-172.

Pos, Riau. (2009). 50.000 Pendukung mega-pro merahkan bukit sampah. Edisi tanggal, 25 Mei 2009, hlm. 1 dan 11.
Pos, Riau. (2009). Awasi netralitas tentara. Edisi tanggal, 26 Mei 2009, hlm. 1 dan 2.

Pos, Riau. (2009). JK janjikan riau di kabinet. Edisi tanggal, 14 Juni 2009, hlm. 1 dan 7.

Pos, Riau. (2009). Mega-SBY-Kalla santun. Edisi tanggal, 19 Juni 2009, hlm. 1 dan 11.

Pos, Riau. (2009). Presiden SBY puji riau. Edisi tanggal, 20 Juni 2009, hlm. 1 dan 11.

Pos, Riau. (2009). Di riau, SBY kritik mega. Edisi tanggal, 21 Juni 2009, hlm. 1 dan 7.

Pos, Riau. (2009). Prabawo baca notes, boediono make up ulang, wiranto ngopi. Edisi tanggal, 24 Juni 2009, hlm. 1 dan 2.

Pos, Riau. (2009). JK enjoy, sby terkekeh, mega kikuk. Edisi tanggal, 26 Juni 2009, hlm. 1 dan 11.

Pos, Riau. (2009). Capres janji siap kalah. Edisi tanggal, 3 Juli 2009, hlm. 1 dan 8.

Pos, Riau. (2009). SBY-Boediono menang mutlak di riau. Edisi tanggal, 9 Juli 2009, hlm. 1 dan 2.

Pekanbaru, Tribun. (2009). 37 Simpatisan mega-pro pingsan. Edisi tanggal, $25 \mathrm{Mei}$ 2009, hlm. 1 dan 7.

Pekanbaru, Tribun. (2009). PD kaget ani diminta jilbab. Edisi tanggal, 28 Mei 2009, hlm. 1 dan 7.

Pekanbaru, Tribun. (2009). PD kaget ani diminta jilbab. Edisi tanggal, 29 Mei 2009, hlm. 1 dan 7.

Pekanbaru, Tribun. (2009). Mega diisiki, SBY ngopi JK dipijit. Edisi tanggal, 19 Juni 2009, hlm. 1 dan 7.

Pekanbaru, Tribun. (2009). SBY: saya masih ingat gelar riau saya. Edisi tanggal, 20 Juni 2009, hlm. 1 dan 7.

Pekanbaru, Tribun. (2009). Kasih Saya modal pak SBY. Edisi tanggal, 21 Juni 2009, hlm. 1 dan 7.

Pekanbaru, Tribun. (2009). Kasih saya modal pak SBY. Edisi tanggal, 24 Juni 2009, hlm. 1 dan 7.

Pekanbaru, Tribun. (2009). JK jadi bintang debat. Edisi tanggal, 26 Juni 2009, hlm. 1 dan 7.

Pekanbaru, Tribun. (2009). 2014 tak usah pilpres. Edisi tanggal, 3 Juli 2009, hlm. 1 dan 7.

Pekanbaru, Tribun. (2009). Kalla ditinggal sendirian. Edisi tanggal, 9 Juli 2009, hlm. 1 dan 7. 